https://doi.org/10.18485/dpls_pld.2020.6.ch2

81 '276

\author{
Junichi Toyota \\ Osaka City University \\ Borko Kovačević \\ University of Belgrade
}

\title{
WHERE CAN ETHNOLINGUISTICS MEET APPLIED LINGUISTICS?
}

\begin{abstract}
Studies on cross-cultural communication have gained much attention, and in relation to recent surge of ethnolinguistics, a new opportunity has arisen for us to explore a new dimension in language studies. This paper investigates a possible interdisciplinary link between entholinguistics and applied linguistics, hoping to shed a light on a new direction in language teaching and learning. When cultural values are involved, it is beyond what reference or prescriptive grammar can tell us. Therefore, it is claimed that interdisciplinary approach such as ethnolinguistics can enrich current existing teaching and learning methods.
\end{abstract}

Key words: ethnolinguistics, intercultural communication, L2 learning, cognitive frame, prescriptive grammar

\section{Introduction}

In learning foreign languages, one naturally pays due attention to grammar and vocabulary as well as pronunciation and listening ability. This can be seen in a content of common text books. Cross-cultural or intercultural communication has been established as an academic discipline and in recent years, ethnolinguistics has also emerged, providing a new line of linguistic research. The relationship between culture and language can be applied to language teaching and learning. Even with this application, discourse strategies cannot be easily taught based on vocabulary or grammar. This is because the way we talk may be partially 
influenced by culture, suggesting that a true linguistic fluency results from acquisition of cultural fluency. Thus, this paper looks at a relationship between culture and linguistic knowledge in the context of language teaching and learning.

This paper is organised as follows: cultural fluency is first mentioned, followed by several cases of culture influencing languages. Following these, it is argued that the cultural knowledge, leading to cultural fluency, can enrich students' linguistic ability, and prove to be useful in attaining fluency in learning new languages.

\section{Linguistic and cultural proficiency}

Proficiency is what one aims at in learning a new language. In recent years, several benchmarks such as CEFR set various specific goals at each level from beginner to proficiency, and these are commonly divided by four main areas of language skills, e.g. speaking, listening, reading and writing. One may need a good command of grammar or a good set of vocabulary. This type of division is nothing new, and in a way, this has been a traditional approach to language learning. However, in order to hold a natural communication/conversation, one must hold a good grasp of discourse strategies. For this, one should be aware of foreign culture and able to incorporate the knowledge into communication. We tend to focus too much on linguistic fluency including the four skills mentioned above, but a 'real' speaker has a good command of culture, too, including jokes and humours. Does it mean that a learner of German does not need to have a sense of humour in order to be fluent?

Cultural knowledge seems to have been neglected, at least partially, in current major teaching methods. One may find it contradictory, especially facing the much-increased awareness in the importance of intercultural communication. It is indeed true that the current common teaching methods allow students to be able to hold a basic conversation or get away with common situations in our daily life in a foreign language, but this is not enough to be fully and naturally productive in the level of proficiency. The same is applicable to teaching, i.e. teaching methods have to make students aware of cultural as well as linguistic differences. Kovačević and Krajišnik (2015) presents some cases that caused problems in teaching Serbian to foreign students. For instance, kinship terms such as mother may not be identically perceived by all students, especially when 
they come from a culture with a practice of polygamy. Another instance involves a case where living environment poses some unexpected surprise in response. Students from South Africa claim that they are afraid of toads - cane toad (Rhinella marina), an invasive species native to South and Central America. They are introduced to South Africa, and due to its poisonous nature (poison is secreted from grands behind eyes when attacked), people consider this species hazardous. Although there are similar, but smaller species of toad native to Serbia (common toad (Bufo bufo), and European green toad (Bufo viridis)), people normally do not consider them as hazardous.

Linguistic knowledge can bring students very far in the learning process, but cultural knowledge can certainly enrich communicative ability. Let us take a look at some examples that may shed light on cultural fluency.

\section{Examples of cultural knowledge}

Languages normally have regular rules and ad-hoc exceptions. Exceptions are normally taught separately, but a common way of learning is memorising them. Cultural understanding, in one sense, can aid learners to comprehend these exceptions, since some languages are known to be influenced by speakers' living environment, as often represented in linguistic relativity hypothesis. Strong versions of this hypothesis often encounter counter arguments, but regardless of how strong a tie between language and culture can be, one has to admit that language and culture goes hand in hand in our communication, and sometimes culture can be clearly seen in language.

Grammatical gender in Indo-European languages can be a good example. There are a couple of different systems among the IndoEuropean languages concerning the gender distinction, i.e. no distinction, masculine-feminine and masculine-feminine-neuter, as shown in Table 1. It is common to have certain endings to indicate the gender distinction, (e.g. - $a$ ending in Romance languages). Other languages, such as German differentiate gender only in the article. The assignment of gender seems arbitrary in many cases. For instance, 'death' is considered as feminine in Russian (i.e. smert'), but it is masculine in German (i.e. Tod). However, in some cases, one may find an explanation. Russian nož ' knife' is masculine and vilka 'fork' is feminine. This is so due to a Russian superstition that if 
a knife is dropped a male guest will come, and if a fork a female guest can be expected (Corbett 1991). These examples from Russian may illustrate that extralinguistic knowledge, such as mythology, and can help learners to deal with exceptions. Once mythology is an accumulation of cultural knowledge, culture plays an important role in learning vocabulary.

Table 1. Gender distinction in Indo-European languages

\begin{tabular}{|l|l|l|}
\hline No distinction & Masculine-feminine & Masculine-feminine-neuter \\
\hline English & $\begin{array}{l}\text { Romance languages, } \\
\text { Lithuanian }\end{array}$ & $\begin{array}{l}\text { Slavic languages, Indic, } \\
\text { Romanian, Dutch, German }\end{array}$ \\
\hline
\end{tabular}

Another example is cultural practice. Lao, a Kra-Dai language spoken in Laos, has a special way to get on a bus. In English, buses are to be caught or taken, i.e. one catches/takes a bus at a bus stop. Thus, the scene of people waiting at a bus stop or a shelter, as depicted in Figure 1, does not seem unfamiliar to English speakers, and people know what a bus stop/a bus shelter looks like and its function. In Laos, however, buses are to be stopped on a street. Buses come and go on main streets, and people somehow know which one to catch. When they see one they have to catch approaching, they wave or step onto a street to stop the bus (Enfield 2002). Thus, the Lao people normally do not understand what people are doing in Figure 1, and they might say that people are standing/ hanging around a pole or a sign post. The difference observed here may appear to be a mere cultural difference, but it can affect language learning. In this particular case, learning how to catch a bus involves linguistic learning (i.e. acquisition of new vocabulary) as well as cultural practice and background (including how to distinguish a specific bus from others). Therefore, learning a phrase may not suffice to create a linguistic base to hold a natural conversation. In this case, one may need to be aware of differences in how to catch a bus in these two cultures.

The case involving Loa may be an obvious case, in a sense that they do not have a cultural practice and it is visible once a learner visits Laos. However, there are other cases that may not be so obvious to understand why unfamiliar linguistic pattern is visible. These cases require further explanations. In what follows, several such cases are shown. 


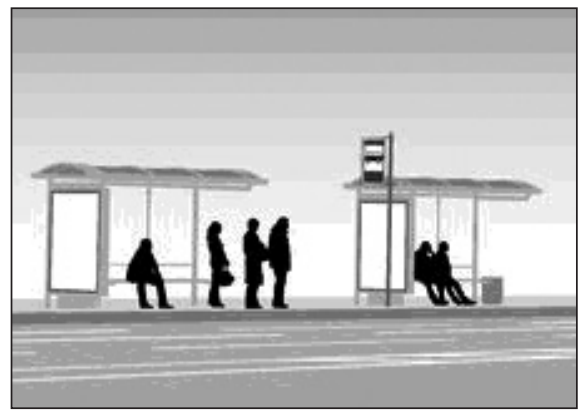

Figure 1. People waiting at a bus stop

\section{Tense and future tense marking in English}

The case of future tense marker in English may not be so obvious, but this shows how religion as a cultural practice can play a certain role in language usage. Toyota (2012) analyses the formation of future tense in relation to culture, claiming that speaker's worldview on death and afterlife influences whether a language in question has a future tense or not, and different worldviews result in different developmental paths. Furthermore, when people's worldview has changed according to social changes, grammatical forms also seem to be adjusted according to a new worldview. Concept of death/afterlife has not been considered in relation to grammar, but there seems to be a close relationship between them. A key factor discussed in his paper is that certainty of future existence after death is reflected on the tense system, and the assurance of future existence through concepts such as reincarnation corresponds to the lack of future tense. The opposite holds true, i.e. when there is no means to know what happens after death, a specific future tense come to be created. When the future existence is not clearly identified, people naturally become afraid of facing death, suggesting that fear or uncertainty concerning future is a key factor in creating a specific future tense form.

A map in Figure 2 reveals the distribution of the future tense in the world languages. Dark dots show languages with an overtly marked future tense, and white dots, languages without future tense. By a quick glance, it becomes apparent that white dots cluster around East and Southeast Asia, where Buddhism (including different branches) is commonly practiced. This religious practice normally assumes what happens when people die, and this is particularly strong in Tibetan Buddhism. Knowing what happens after death in advance relieves fear, which results in not paying attention to future. 


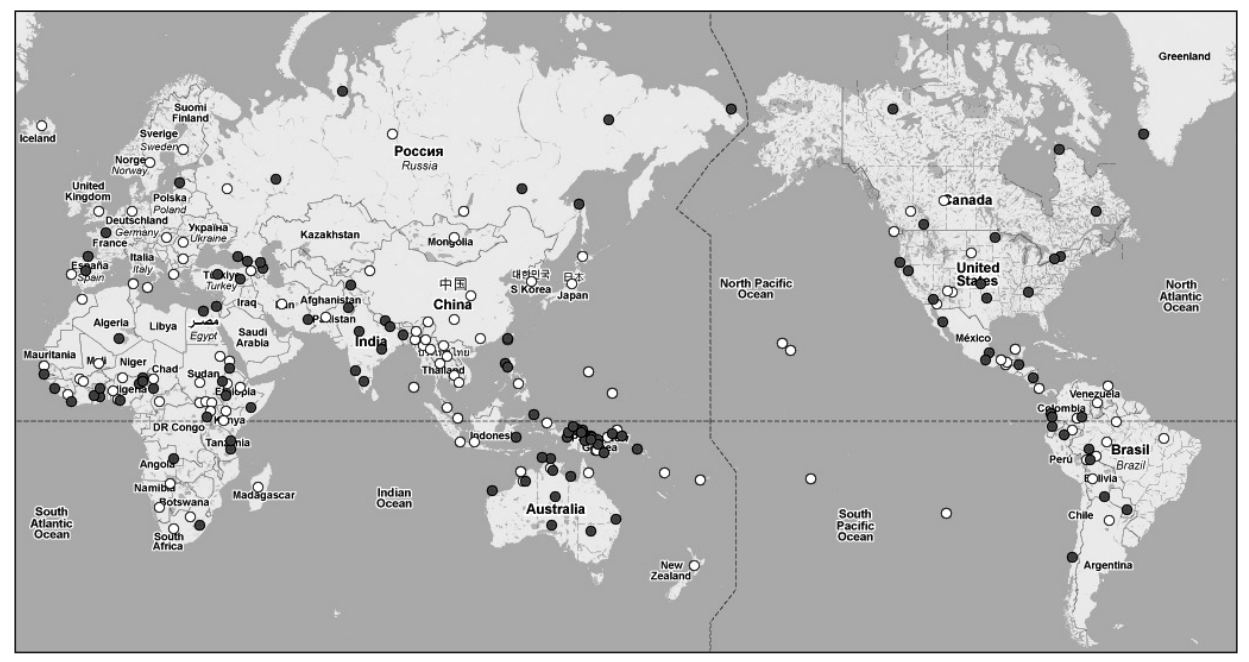

Figure 2. Geographic distribution of the future tense (Dahl and Velupillai 2008)

When the distribution of the future tense and belief systems is considered, the correspondence concerning the distributional pattern becomes even more clearly visible. Among different religious beliefs, it is common to find cultures that do not clarify the future existence, and many have tried to cope with this in different ways. One common way is to postulate heaven and hell. This will allow religious organisations to manipulate people and keep them faithful to their belief. A clear exception for this is Asia, where various native cultures tend to incorporate the future existence in their doctrine and followers know the course of actions after they die. Interestingly, languages spoken in Asia lack the overtly marked future tense (cf. Dahl \& Velupillai 2008). In addition, different belief systems concerning death/afterlife also influence the sources for the grammaticalisation of the future tense (cf. Bybee et al. 1994; Heine and Kuteva 2002, Toyota 2012, etc.). For instance, in paganism, future is predestined for everyone by god and humans cannot alter its course, i.e. future is a destiny. Languages spoken in such cultures often incorporate expressions of obligation to express futurity, reflecting the lack of ability to influence future events. In Christianity or Islam, on the other hand, by postulating heaven and hell, futurity becomes uncertain and depending on followers' deeds, a decision is made at their death. In this case, believers want/wish to stay in conform after death, leading to the source of expressions concerning wish or desire. Thus, sources for grammaticalisation can also be related to different worldview. 
This case is not a case study of the Buddhist culture, but this line of argument seems to be applicable to different language groups in different parts of the world. When it comes to the diversity of future tense and historical development, there are several grammaticalisation paths of the future tense. Some are more common and others rarer. Heine and Kuteva (2002) presents motion verbs, modality and verbs of desire as typologically common developmental paths. Interestingly, English has covered all of these common paths along with an inchoative verb 'become'. However, these changes occurred at different periods and some co-existed. A verb of desire will 'want' eventually seems to have won the competition and it is now used as the unmarked future tense, since be going to is a near future and shall, which may be somewhat obsolete now as a future tense marker, implies futurity $\mathrm{w}$ a sense of deontic modality, obligation. In the history of English, will (OE willan 'wish, desire'), shall (OE sceall 'owe') and weorðan 'become' existed in Old English as a future tense marker. The motion verb go as a future tense marker in the phrase be going to is added to the other choices from ca. the $18^{\text {th }}$ century (s.v. OED go v.47.b). The chronology is schematically summarised in Figure 4. The dotted line represents that the form was present, but not frequently used, i.e. either decline or increase in frequency. Toyota (2012) argues that this shift in expressing futurity is not a mere coincidence, but the changes in form resulted from a shift in religious belief and worldview on death and afterlife.

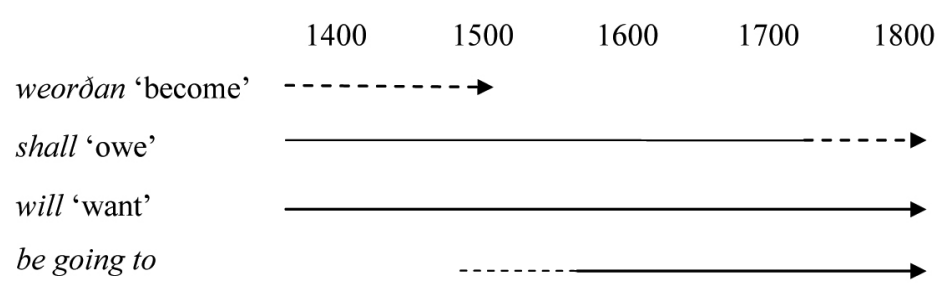

Figure 4. Diachrony of future tense markers

Depending on the source of grammaticalisation, some forms retain partial original meanings, and this is the case in shall. Its original lexical meaning, 'owe', is retained as deontic modality and this is still preserved in its use as a future tense marker, especially in the second and third person, but not in the first person. Thus, the first person form, I/we shall $d o$, can be an unmarked future tense, but the rest can be a future tense with deontic modality, i.e. you/he/she shall do 'you/he/she will have to 
do', e.g. "The usage as to the choice between the two auxiliaries has varied from time to time; since the middle of the 17 th $\mathrm{c}$. the general rule (subject to various exceptions) has been that mere futurity is expressed in the first person by shall, in the second and third by will" (s.v. OED shall v. 8). Thus, shall is indeed a future tense marker, but at the same time defective in terms of markedness in its semantics, i.e. "sceal (shall) even when rendering a Latin future, can hardly be said to have been ever a mere tense-sign in OE.; it always expressed something of its original notion of obligation or necessity" (s.v. OED shall v. 8). English has not really fixed this defectiveness and this can be a reason for its decline in use. However, in relation to this defective system, there seems to be some other causes for decline. Semantic residues are less likely to be found in will and be going to, but their original core meaning can serve as an indicator of earlier religious culture.

Like other Germanic languages of the same period, Old English used an inchoative verb 'become', i.e. weorðan. In Modern German, for instance, its cognate werden 'become' still functions as a future tense marker (s.v. OED worth $v^{l} 3 a, b$ ). What is noticeable in case of older English in comparison with other older Germanic languages is that in spite of its functional load, weorðan 'become' had been steadily in decline in use and it was nearly extinct by the end of the $16^{\text {th }}$ century (s.v. OED worth v. ${ }^{1}$ ) and this still remains mystery in the history of English (Strang 1970: 351). What is interesting in weorðan 'become' is its etymon, i.e. 'fate'. Indo-European, including Anglo-Saxon, commonly believed that their life is predestined, i.e. fate, and the idea stems from the earlier Pagan belief (West 2007: 379). It is common that human life is compared to a thread, and life was often said to be determined by the action of spinning. In Old English, wyrd is a term used for human fate, possessing a power to weave destinies. The examples me pæt Wyrd gewāf. and prāg... wefen wyrdstafum from Old English poetry illustrate how pervasive this idea was earlier. Wyrd shares the same etymon with weorðan 'become', and future reference found in weorðan is a residue of earlier Indo-European Pagan belief in fatalism. Since fate played a central role in the earlier world view, death was also considered as a part of fate, and one was predestined to die at a certain time and in a certain manner. However, Indo-European distinguished two kinds of death, a natural death (i.e. death by fate, death of one's birth right) and a premature death caused by outer force (i.e. violence, drowning, etc.). Regardless of how one dies, however, they did 
not fear death, since it was already programmed as such and one could not alter the course of life. This is perhaps why many preferred fame to longevity.

$$
\begin{array}{llll}
\text { me } & \text { poet } & \text { Wyrd } & \text { gewāf. } \\
\text { I.DAT } & \text { that.ACC } & \text { fate } & \text { weave.PST }
\end{array}
$$

'Wyrd wove that for me.' (Rhyme Poem 70)

$$
\begin{array}{cc}
\operatorname{pra\overline {g}...} \quad \text { wefen } & \text { wyrdstafum } \\
\text { time weave.PST.PRT } & \text { fate's.loom.DAT } \\
\text { 'the time woven on Wyrd's loom.' (Guthlac } 1350 \mathrm{f} .)
\end{array}
$$

Thus, earlier religious belief, especially ideas concerning death and afterlife, plays an important role in this. Furthermore, if belief is reflected on the tense system, shifts of belief can affect the tense system. Thus, the evolutionary onset of the future tense is connected to fear/uncertainty of what might happen after death. Earlier pagan considered death as fate, and one 'must' follow what life has been programmed. However, Christianity intentionally makes afterlife ambiguous, i.e. one never knows what to do in order to guarantee a place in heaven. Nothing is enough in this respect. This makes the followers 'want' to go to heaven. This kind of fear is absent in languages spoken in Asia because of their belief in reincarnation.

In Present-Day English, there are three ways to refer to futurity in English, i.e. will, shall and be going to, and differences among them may not be so straightforward. Learners may be confused as to which future tense marker is to be chosen, but once historical as well as cultural backgrounds are taken into consideration, a choice can become easier to make.

\section{Perception verb and metaphor of cognition}

As Toyota and Richards (2017) show, expressions of perception particularly involving metaphor can be influenced by cultural differences. Metaphor of cognition can be attested in English as in I see your point. The source domain in this case is visual perception, and the target domain, cognition. This type of conceptual metaphor is commonly found in different languages regardless of the language family, and this has been sometimes considered universally found in the world languages. The vision-related metaphors were a sign that vision plays a central role in 
human perception. Viberg (1984: 136) presents a hierarchical order of perception, as represented in Figure 5.

\begin{tabular}{|c|c|c|c|c|c|c|}
\hline Sight & $>$ & Hearing & $>$ & Touch & $>$ & $\begin{array}{c}\text { Smell } \\
\text { Taste }\end{array}$ \\
\hline
\end{tabular}

Figure 5. Hierarchical order of perception

Further evidence can be found in historical data. Earlier verbs of vision developed into verbs of knowledge in Indo-European languages through metaphorisation, i.e. a Proto-Indo-European verb *weyd 'see' became the English wise or wit or Irish fios 'knowledge'. Similarly, the development of the Proto-Germanic wáit 'I know' originates from the same Proto-Indo-European verb, but its perfective sense 'I have completed seeing' was not shifted to the past tense 'I saw/have seen' as normally found in grammaticalization concerning the perfective aspect, but rather to 'I know'. One may not be aware that the verb 'know' is related to vision in modern languages, e.g. the German wissen 'know', but instances like these show the dominance of vision in human cognition. This vision-centred perception is schematically represented in Figure 6, which suggests the applicability of vision to other perceptions.

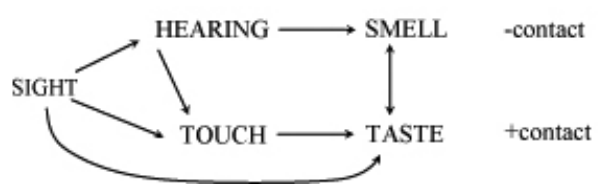

Figure 6. Semantic extensions in perceptual modalities (Viberg 1984: 147)

However, research dealing with less-known languages revealed an audio-dominant perception type, i.e. Evans and Wilkinson (2000) report a case of languages in Australia and Papua New Guinea where a verb of hearing plays a major role, and Thanassoula (2013) presents a different type of data from the Bantu languages spoken in East Africa. In these languages, a verb of hearing plays a major role and it is used as a base for a metaphorical extension referring to cognition, e.g. 'I hear your point' meaning 'I understand your point'. For instance, an Australian language Pitjantjatjara has a verb kulini 'hear', as in (3a), and it is highly polysemous. Among various senses, this verb can be used as a verb of cognition, as exemplified in (3b). 
(3)a. Ngayulu anangu-ngkuwangkanytjala

kulinu I people-ERG talk.NOMZR.LOC hear.PST 'I hear people talking.'

$\begin{array}{llll}\text { b. Mutuka/ compyter ngayulu putu } & \text { kulini } \\ \text { car computer I In.van understand.PRS }\end{array}$

'I don't understand cars/computers.'

Pitjantjatjara (Australian, Evans and Wilkinson 2000: 563, 564)

This is not what is expected in, for instance, Indo-European languages. What is unique and makes a sharp contract against the IndoEuropean counterparts in these languages is that verbs of hearing seem to be the prime source for semantic extensions. Evans and Wilkinson (2000) revise Figure 6 as Figure 7. In Figure 7, it is clear that the verb of hearing plays a central role, and the dotted line here shows a dubious case and this extension is dependent on how one interprets data and thus they leave it open for interpretation.

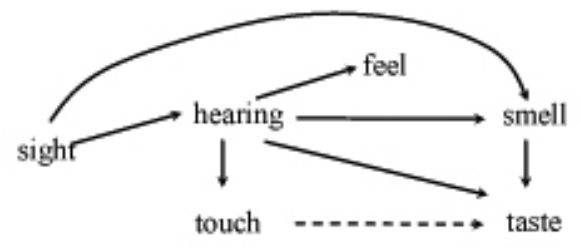

Figure 7. Semantic extensions across perceptual modalities in Australian languages (Evans and Wilkinson 2000: 560)

The diversity here is surely a puzzle to many, and a possible interpretation can be found in cultural difference. Sasha Aikhenvald (p.c.) suggests that those languages that put emphasis on the verb of hearing are spoken in a culture where religiously-gifted people (i.e. shamans, spiritual healers, etc.) have a special power and a social role in their local society. They are believed to be able to see 'everything', including ancestral spirits. Thus, the verb of vision is reserved to these gifted people and the common people have resorted to the second most prominent perception, i.e. hearing. As shown in Figure 7, vision still plays an important role, but due to cultural values and practices, metaphorisation is organised around audio-sensory. This is how the verb of hearing became prominent in languages in specific parts of the world. 
The fact that religious-culture influences how metahorisation is made can be seen in data presented by Thanassoula (2013), dealing with languages spoken in East Africa, where an olfactory verb can be a base for semantic extension. She reports the case of Lussesse, a Bantu language spoken on the Ssesse Island in Lake Victoria. This language also has a highly polysemous verb of hearing -húlirà, similar to Australian and Papuan languages. This suggests a close link between the use of perception verbs and local religions. What is peculiar in East Africa is that there is a local belief that ancestors communicate through smell according to a local religion in the region, and only religiously-gifted people can interpret smells. In this culture, smell gains a special status among five basic perceptions, unlike anywhere else in the world. As Figure 8 shows, -núuka 'smell good' can be extended to cognition, and this use is only found among religious people, and common people use the verb of hearing for various extensions including cognition. The use of an olfactory verb as a base for semantic extension is typologically rare, but the case in East Africa reinforces a link between religious influence and use of perception verbs as suggested by Aikhenvald.

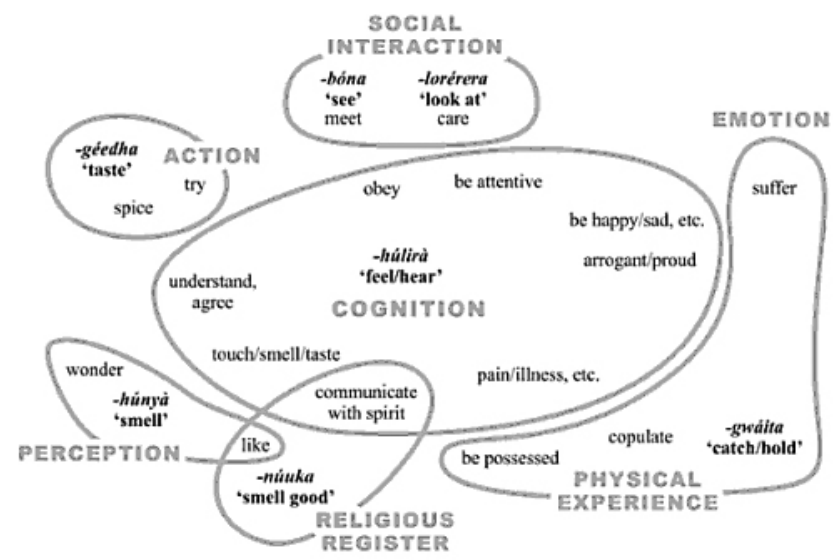

Figure 8. Lussesse (Bantu) perception (Thanassoula 2013: 255)

It may be rare to learn langauges with audio- or olfactory-oriented perception, unless a learner is a linguisit or an anthropologist. However, this case can also suggest that knowing cultural background makes it much easier to understand why what appears to be an uncommon pattern can be found in some langugaes. 


\section{Concluding remarks}

We take our living environment, including culture, as a base for conceptualising the world. This base is also used in learning a new language, and it is not surprising that it influences the learning in both positive and negative way. Examples presented so far present rare cases of relationship between language and culture, which may be considered as odd to learners. Since the difference is so striking, as often discussed in ethnolinguistics, learners may find it very difficult to learn a language to the level of proficiency, except for learning each case as a separate instance. However, once cultural background, i.e. cultural knowledge, is given to learners, these odd linguistic forms and usage can be easily understood. Different cultural values are indeed found in different languages, even among languages in a same linguistic family. Culture, thus, is an important factor in attaining proficiency in language teaching and learning.

Language learning is not merely familiarising what textbooks say, including vocabulary and grammar. As this paper has presented, a firm grasp of culture often results in better understanding. Disciplines such as ethnolinguistics can help us to develop a new line of research in language teaching and learning. It is suggested here that teaching culture can bear fruitful results in applied linguistics in the future.

\section{References}

Bybee, J., Perkins, R. and Pagliuca, W. (1994). The Evolution of Grammar: Tense, Aspect, and Modality in the Languages of the World. Chicago: University of Chicago Press.

Corbett, G. (1991). Gender. Cambridge: Cambridge University Press.

Dahl, Ö. and V. Velupillai (2008). The future tense. In: Haspelmath, M., M. S. Dryer, D. Gil and B. Comrie (eds.). The World Atlas of Language Structures Online. Munich: Max Planck Digital Library, chapter 67. Available online at http://wals.info/feature/39. Accessed on $<19$ November 2010 $>$

Enfield, N. (2002). Cultural logic and syntactic productivity: associated posture constructions in Lao. In Ethnosyntax: explorations in grammar and culture (N. Enfield, ed.), Oxford: Oxford University Press, 231-258.

Evans, N. \& D. Wilkins (2000). In the Mind's Ear: the Semantic Extensions of Perception Verbs in Australian Languages. Language 76, 546-591.

Heine, B. and T. Kuteva (2002). World Lexicon of Grammaticalization. Cambridge: Cambridge University Press. 
Kovačević, B. and V. Krajišnik (2015). Neka lingvokulturološka zapažanja $\mathrm{u}$ nastavi srpskog kao stranog jezika. In Applied linguistics today challenges of modern times (V. Polovina and S. Gudurić, eds.), Beograd:

Društvo za primenjenu lingvistiku Srbije, Filološki fakultet u Beogradu i Filozofski fakultet u Novom Sadu, 135-140.

OED (Oxford English Dictionary) (1989) (2nd ed.). Oxford: Clarendon Press. Strang, B. (1970). A History of English. London: Routledge.

Thanassoula, M. (2013). Perception in Lussesee (Bantu, J10). In Perception and

Cognition in Language and Culture (A. Aikhenvald and A. Storch, eds.), Leiden: Brill, 251-270.

Toyota, J. (2012). Concept of Time: a Case of Future Tense. In Sense of Emptiness: an interdisciplinary perspective (J. Toyota, P. Hallonsten and M. Shchepetunina, eds.), Newcastle upon Tyne: Cambridge Scholars Publishing, 187-208.

Toyota, J. and I. Richards (2017). Different Views on Vision. In Vision beyond Visual Perception (J. Toyota, I. Richards, B. Kovačević and M. Shchepetunina, eds.), Newcastle upon Tyne: Cambridge Scholars Publishing, 1-8.

Viberg, A. (1984). The Verbs of Perception: a Typological Study. In Explanations for Language Universals (B. Butterworth, B. Comrie and Ö. Dahl, eds.), Berlin: Mouton de Gryuter, 123-162.

West, M. L. (2007). Indo-European Poetry and Myth. Oxford: Oxford University Press.

\section{Đunići Tojota, Borko Kovačević}

\section{ETNOLINGVISTIKA U ISPOMOĆI PRIMENJENOJ LINGVISTICI}

Sažetak: Međukulturna komunikacija u poslednje vreme privlači sve veću pažnju istraživača iz različitih oblasti. $U$ tom svetlu, etnolingvistika može dati značajan doprinos primenjenoj lingvistici, a na prvom mestu u domenu nastave stranih jezika. Ovaj rad upravo se bavi interdisciplinarnom vezom entolingvistike i primenjene lingvistike, u potrazi za jednom novom dimenzijom u predavanju i učenju stranih jezika. Kada su u pitanju kulturne vrednosti, to je često van onoga što se može naći u tipičnim udžbenicima ili u gramatikama. U tom smislu, ovde se pokazuje da jedan interdisciplinarni pristup, kao što u sebi imaju etnolingvistička istraživanja, može značajno obogatiti i poboljšati postojeće metode nastave stranog jezika.

Ključne reči: etnolingvistika, interkulturna komunikacija, nastava stranog jezika 